\title{
Catellibacterium nanjingense sp. nov., a propanil-degrading bacterium isolated from activated sludge, and emended description of the genus Catellibacterium
}

Correspondence

Jian $\mathrm{He}$

hejian@njau.edu.cn

\author{
Jun Zhang, ${ }^{1} \dagger$ Shu-An Chen, ${ }^{2} \dagger$ Jin-Wei Zheng, ${ }^{1}$ Shu Cai, ${ }^{1}$ Bao-Jian Hang, ${ }^{1}$ \\ Jian $\mathrm{He}^{1}$ and Shun-Peng $\mathrm{Li}^{1}$ \\ ${ }^{1}$ Key Laboratory for Microbiological Engineering of Agricultural Environment of Ministry of \\ Agriculture, Nanjing Agricultural University, Nanjing 210095, PR China \\ ${ }^{2}$ China National Center for Biotechnology Development, Beijing 210095, PR China
}

The genus Catellibacterium, belonging to the 'Rhodobacter' clade of the family Rhodobacteraceae of the class Alphaproteobacteria, was proposed by Tanaka et al. (2004). At the time of writing, the genus includes four species: Catellibacterium nectariphilum (Tanaka et al., 2004), C. aquatile (Liu et al., 2010), C. caeni (Zheng et al., 2011) and C. changlense (Anil Kumar et al., 2007; Zheng et al., 2011). In this study, a propanil-degrading bacterial strain, designated $\mathrm{Y} 12^{\mathrm{T}}$, was isolated from activated sludge of a wastewater bio-treatment facility. Based on the results of a polyphasic taxonomic study, this strain is considered to represent a novel species of the genus Catellibacterium.

Propanil (3,4-dichloropropionanilide) is an acetanilide post-emergence herbicide, which is widely used against

†These authors contributed equally to this work.

The GenBank/EMBL/DDBJ accession number for the 16S rRNA gene sequence of strain $Y 12^{\top}$ is EU289803.

Three supplementary figures and a supplementary table are available with the online version of this paper. numerous grasses and broad-leaved weeds in rice, potatoes and wheat. This herbicide is moderately toxic to humans due to its potential to irritate eyes and skin, and is highly toxic to a wide range of aquatic species. One of the major breakdown pathways of propanil in the soil, sediment and water is by microbial degradation (Weed Science Society of America, 1994). To isolate propanil-degrading bacteria, a conventional enrichment procedure was carried out in 10fold-diluted LB broth supplemented with $100 \mathrm{mg}$ propanil $^{-1}$ (Wang et al., 2009). The 10-fold-diluted LB broth contained (per litre) $1.0 \mathrm{~g}$ tryptone, $0.5 \mathrm{~g}$ yeast extract and $1.0 \mathrm{~g} \mathrm{NaCl}$. The sludge sample used as the initial inoculant was collected from a wastewater bio-treatment facility in a pesticide manufacturing company in Nanjing city, Jiangsu province, PR China. After five successive steps of subcultivation, the enrichment culture was spread on 10fold-diluted LB agar supplemented with $100 \mathrm{mg}$ propanil $^{-1}$, and incubated at $30{ }^{\circ} \mathrm{C}$ for $4-5$ days. Strain $\mathrm{Y}^{2}{ }^{\mathrm{T}}$ was obtained after several streakings and transferred onto fresh plates. C. caeni DCA $-1^{\mathrm{T}}$, C. aquatile $\mathrm{A} 1-9^{\mathrm{T}}$, C. nectariphilum JCM $11959^{\mathrm{T}}$ and C. changlense JCM $14338^{\mathrm{T}}$ were 
employed as controls in phenotypic tests. Unless otherwise mentioned, these strains were grown aerobically on 10fold-diluted LB agar or in 10-fold-diluted LB broth at $30{ }^{\circ} \mathrm{C}$.

Cell morphology and dimensions were determined by transmission electron microscopy (H-7650; Hitachi). In preparation for electron microscopy, bacterial cells were suspended in $0.85 \% \mathrm{NaCl}$. Subsequently, the cells were dried on a nickel-coated mesh, negatively stained with phosphotungstic acid and examined. The motility of cells was tested by the hanging drop method (Suzuki et al., 2001). The internal membrane structures were viewed with a transmission electron microscope after the cells had been processed as described by Hanada et al. (2002). Gram staining and the $\mathrm{KOH}$ lysis test were carried out according to Gregersen (1978) and Buck (1982), respectively. Growth was tested at different temperatures $(4,10,15,25,28,30$, $35,37,40$ and $\left.45{ }^{\circ} \mathrm{C}\right), \mathrm{pH}(5.0-10.0$, in increments of 0.5 $\mathrm{pH}$ units), and $\mathrm{NaCl}$ concentrations [final concentrations of $0-7.0 \%(\mathrm{w} / \mathrm{v})$ at increments of $0.5 \%]$ in 10 -fold-diluted LB broth. Anaerobic growth was assessed in serum bottles containing 10-fold-diluted LB broth and sodium thioglycolate $\left(1 \mathrm{~g} \mathrm{l}^{-1}\right)$ with the upper air layer replaced with nitrogen gas. The catalase test was carried out as described previously (Ohta \& Hattori, 1983). Growth on TSA (Difco) was evaluated at $30{ }^{\circ} \mathrm{C}$ for $72 \mathrm{~h}$. Hydrolysis of starch, Tweens 20 and 80, and tyrosine was determined as described by Cowan \& Steel (1965). Other physiological and biochemical tests were assayed by using API ZYM and 20NE strips (bioMérieux) according to the manufacturer's instructions. Phototrophic growth was assessed in the minimal medium of Pfennig \& Trüper (1974) in completely filled screw-cap bottles under incandescent illumination (2000 lx); sodium succinate, sodium malate, sodium pyruvate, sodium citrate and glucose $\left(4.0 \mathrm{~g} \mathrm{l}^{-1}\right)$ were supplemented as electron donors. Ability to degrade propanil was determined according to the methods described by Guo et al. (2009); the propanil was added at a final concentration of $40 \mathrm{mg} \mathrm{l}^{-1}$.

Strain $\mathrm{Y} 12^{\mathrm{T}}$ was facultatively anaerobic and the cells were Gram-stain-negative, non-motile, non-sporulating rods covered with a thick slime layer (Fig. 1). Colonies were white to beige, convex and circular with entire margins. The strain grew in the presence of $0-4.5 \%(\mathrm{w} / \mathrm{v}) \mathrm{NaCl}$ (optimum $0.5 \%$ ), at $10-40{ }^{\circ} \mathrm{C}$ (optimum $28{ }^{\circ} \mathrm{C}$ ) and at pH 5.5-10.0 (optimum $\mathrm{pH}$ 7.0). Strain $\mathrm{Y} 12^{\mathrm{T}}$ was able to degrade about $90 \%$ of added propanil $\left(100 \mathrm{mg} \mathrm{l}^{-1}\right)$ within 3 days of incubation. A vesicular internal membrane structure was not detected and photoheterotrophic growth was not observed. Detailed morphological, physiological and biochemical characteristics of strain $\mathrm{Y}_{12} 2^{\mathrm{T}}$ are summarized in the species description below and in Table 1. The HPLC data of propanil degradation by strain $\mathrm{Y}_{12}^{\mathrm{T}}$ is shown in Supplementary Fig. S1 (available in IJSEM Online).

Genomic DNA was extracted according to standard procedures (Sambrook \& Russell, 2001). The G + C content

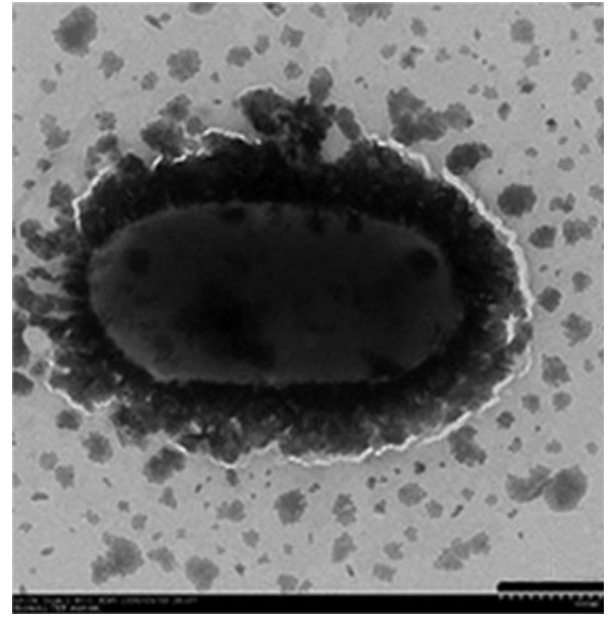

Fig. 1. Transmission electron micrograph of a negatively stained cell of strain $\mathrm{Y}_{12}{ }^{\top}$, characterized by short, non-spore-forming rods, no flagella and a thick slime layer. Bar, $0.5 \mu \mathrm{m}$.

of the genomic DNA was determined by thermal denaturation (Mandel \& Marmur, 1968). The 16S rRNA gene was amplified by PCR and sequenced as described by Wang et al. (2011). Calculations of pairwise sequence similarity were carried out using the EzTaxon server (http://www.eztaxon. org/; Chun et al., 2007). Phylogenetic analysis was performed using MEGA version 4.1 (Tamura et al., 2007). Distances were calculated by using distance options according to Kimura's two-parameter model (Kimura, 1980) and clustering was performed by using the neighbour-joining method (Saitou \& Nei, 1987). Bootstrap analysis of 1200 resamplings was used to evaluate tree topology (Felsenstein, 1985).

An almost complete 16S rRNA gene sequence (1334 nt) was obtained for strain $\mathrm{Y}_{12}{ }^{\mathrm{T}}$. Phylogenetic analysis based on $16 \mathrm{~S}$ rRNA gene sequence revealed that strain $\mathrm{Y}^{2} 2^{\mathrm{T}}$ was a member of the genus Catellibacterium and was related most closely to C. caeni DCA $-1^{\mathrm{T}}$ (99.1\% sequence similarity); it showed less than $96.0 \% 16 \mathrm{~S}$ rRNA gene sequence similarity to C. aquatile A1-9 $9^{\mathrm{T}}(95.9 \%)$, C. changlense JCM $14338^{\mathrm{T}}$ (95.3\%), C. nectariphilum JCM 11959 (93.6\%). In the neighbour-joining phylogenetic tree, strain $\mathrm{Y} 12^{\mathrm{T}}$ formed a clade within the genus Catellibacterium (Fig. 2; Supplementary Fig. S2).

DNA-DNA hybridization is necessary to clarify the taxonomic relationship of strains when these strains share more than $97 \%$ 16S rRNA gene sequence identity (Tindall et al., 2010). To further clarify the taxonomic relationship of strain $\mathrm{Y}_{12}{ }^{\mathrm{T}}$ with its closest phylogenetic neighbour, C. caeni DCA $1^{\mathrm{T}}$, DNA-DNA hybridization was performed in triplicate with photobiotin-labelled probes as described by Ezaki et al. (1989). Additionally, reciprocal analysis was carried out to avoid any inconsistency during DNA binding. DNA-DNA hybridization 
Table 1. Phenotypic characteristics that differentiate strain $Y 12^{\top}$ from type strains of the genus Catellibacterium

Taxa: 1 , Y12 ${ }^{\mathrm{T}}$; 2, C. caeni DCA-1 ${ }^{\mathrm{T}} ; 3$, C. aquatile A1-9 ${ }^{\mathrm{T}} ; 4$, C. changlense JCM $14338^{\mathrm{T}} ; 5$, C. nectariphilum JCM $11959^{\mathrm{T}}$. + , Positive reaction; - , negative reaction. Data on the requirement for diffusible compounds from other bacterial cultures for vigorous growth from Tanaka et al. (2004); other data from this study.

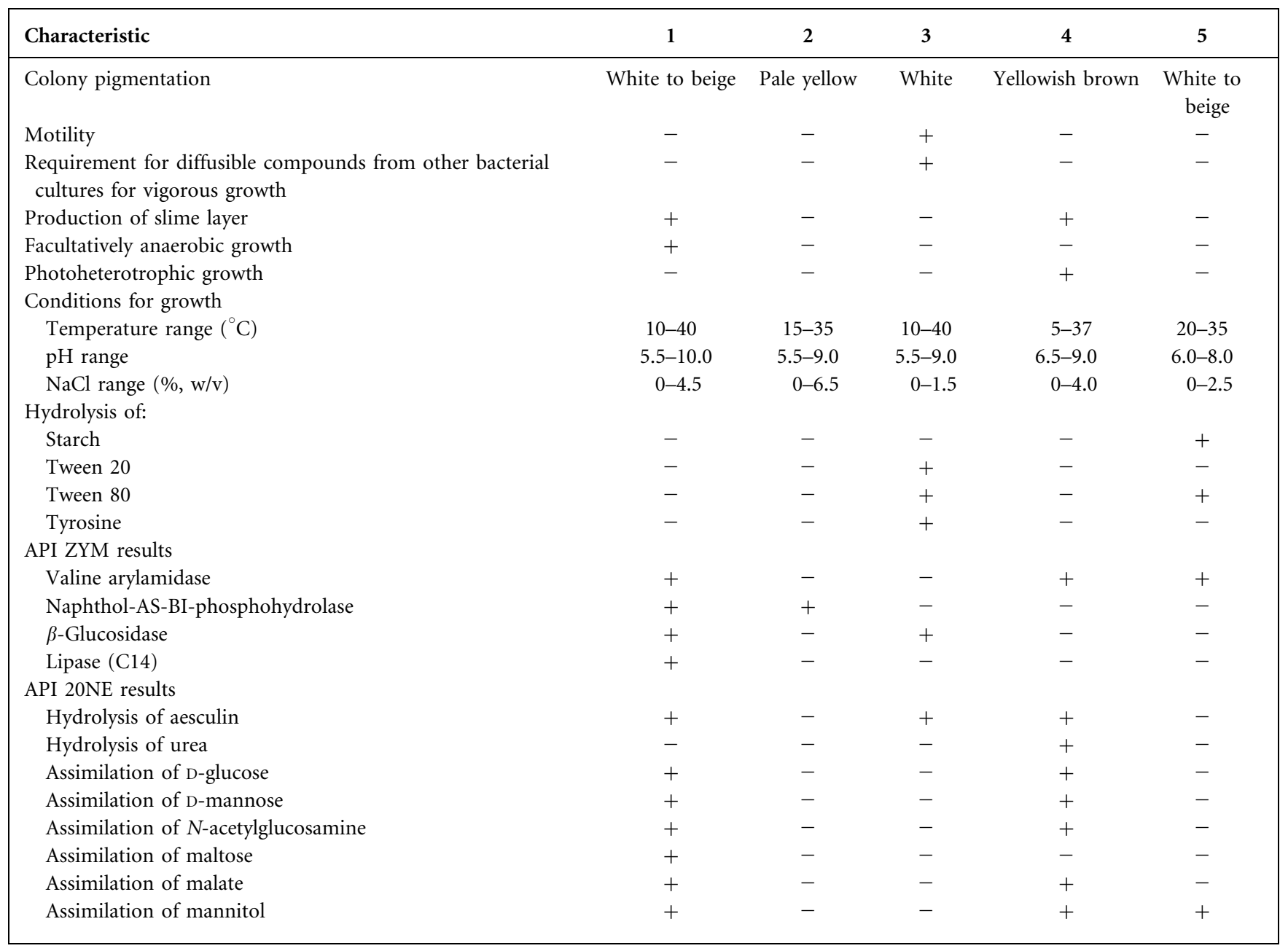

results indicated low levels of relatedness between strain $\mathrm{Y} 12^{\mathrm{T}}$ and $C$. caeni DCA $-1^{\mathrm{T}}$ (18.9\%; reciprocal, $\left.14.3 \%\right)$. These values are well below the threshold of $70 \%$ that is suggested for species delineation (Wayne et al., 1987), indicating that strain $\mathrm{Y} 12^{\mathrm{T}}$ represents a separate genomic species.

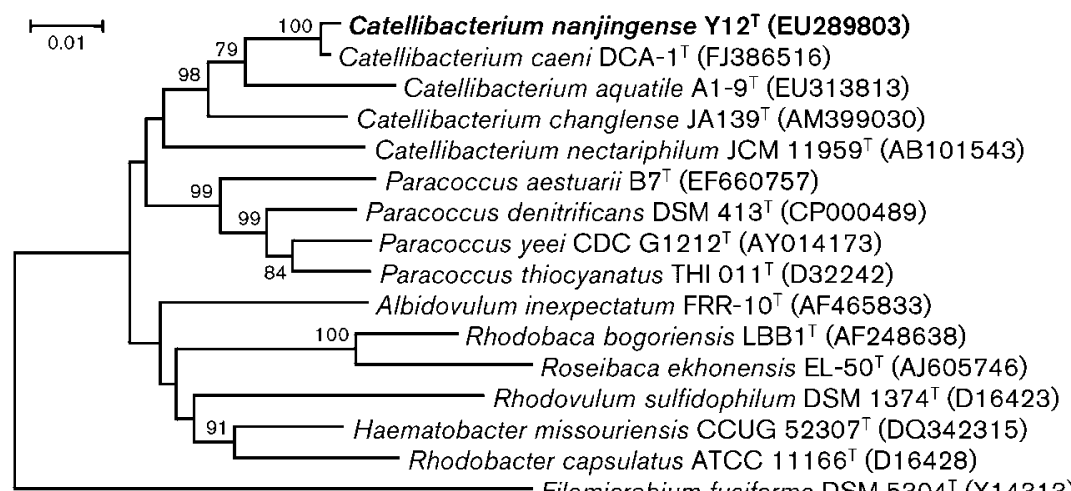

- Filomicrobium fusiforme DSM $5304^{\top}$ (Y14313)
Fig. 2. Phylogenetic tree reconstructed by the neighbour-joining method based on $16 \mathrm{~S}$ rRNA gene sequences of strain $\mathrm{Y} 12^{\top}$ and type strains of the genus Catellibacterium. Filomicrobium fusiforme DSM $5304^{\top}$ was used as an outgroup. Bootstrap values, generated from 1200 resamplings, at or above $70 \%$ are indicated at branch points. Bar, $0.01 \mathrm{nt}$ substitutions per nucleotide position. 
The cell mass of strains used for chemotaxonomic analyses was produced on 10-fold-diluted LB agar incubated at $30{ }^{\circ} \mathrm{C}$ for 3 days. Isoprenoid quinones were extracted and purified according to the method of Collins et al. (1977) and analysed by HPLC as described by Kroppenstedt (1982). Cellular fatty acids were extracted, methylated and analysed by using the Sherlock Microbial Identification System following the manufacturer's instructions. Fatty acid methyl esters were obtained from cells by saponification, methylation and extraction as described by Kämpfer \& Kroppenstedt (1996) and were separated in a gas chromatograph (Agilent 6890N). Peaks were automatically integrated and fatty acid names and percentages were determined using the MIDI Sherlock MIS system (library: TSBA6; version, 6.0B) (Sasser, 1990). Polar lipid analyses were carried out by the Identification Service of the DSMZ and Dr B. J. Tindall, DSMZ, Braunschweig, Germany.

The chemotaxonomic data obtained for strain $\mathrm{Y} 12^{\mathrm{T}}$ were consistent with the assignment of the strain to the genus Catellibacterium (Tanaka et al., 2004; Liu et al., 2010; Zheng et al., 2011). The DNA G $+\mathrm{C}$ content of strain $\mathrm{Y} 12^{\mathrm{T}}$ was $63.7 \mathrm{~mol} \%$. The strain contained ubiquinone-10 as the predominant respiratory quinone. The major cellular fatty acids of strain $\mathrm{Y}_{12}^{\mathrm{T}}$ were summed feature $8\left(\mathrm{C}_{18: 1} \omega 6 \mathrm{c}\right.$ and/ or $\left.\mathrm{C}_{18: 1} \omega 7 c ; 70.9 \%\right), \mathrm{C}_{16: 0}(5.1 \%), \mathrm{C}_{18: 0}(6.6 \%), \mathrm{C}_{10: 0} 3-$ $\mathrm{OH}(4.1 \%)$ and 11-methyl $\mathrm{C}_{18: 1} \omega 7 c(8.8 \%)$. The minor components $\mathrm{C}_{14: 0}(1.9 \%), \mathrm{C}_{18: 0} \quad 3-\mathrm{OH} \quad(1.3 \%)$ and summed feature $3\left(\mathrm{C}_{16: 1} \omega 6 c\right.$ and/or $\left.\mathrm{C}_{16: 1} \omega 7 c ; 2.7 \%\right)$ were also present. The fatty acid profile of strain $\mathrm{Y}_{12}{ }^{\mathrm{T}}$ was similar to those of the type strains of species of the genus Catellibacterium, although the proportions of some major fatty acids were different (Supplementary Table S1).

The polar lipids of strain $\mathrm{Y}_{12}{ }^{\mathrm{T}}$ consisted of diphosphatidylglycerol, phosphatidylglycerol, phosphatidylethanolamine, phosphatidylcholine, phospholipid, an unidentified lipid and an unidentified aminolipid (Supplementary Fig. S3). The polar lipid profile of strain $\mathrm{Y}_{12}{ }^{\mathrm{T}}$ was not identical to those of C. caeni DCA $-1^{\mathrm{T}}$ and C. nectariphilum JCM $11959^{\mathrm{T}}$. Phospholipid (PL1) was absent from the polar lipid profiles of C. caeni DCA-1 ${ }^{\mathrm{T}}$ and C. nectariphilum JCM $11959^{\mathrm{T}}$ but present in strain $\mathrm{Y} 12^{\mathrm{T}}$, glycolipid (GL) was absent in strain $\mathrm{Y}^{2}{ }^{\mathrm{T}}$ and C. caeni DCA-1 ${ }^{\mathrm{T}}$ but present in $C$. nectariphilum JCM $11959^{\mathrm{T}}$.

On the basis of the results of the phylogenetic analysis, morphological and chemotaxonomic investigations, and DNA-DNA hybridization, strain $\mathrm{Y} 12^{\mathrm{T}}$ represents a novel species of the genus Catellibacterium, for which the name Catellibacterium nanjingense sp. nov. is proposed.

\section{Emended description of the genus Catellibacterium Tanaka et al. 2004 emend. Liu et al. 2010 emend. Zheng et al. 2011}

The formal descriptions given by Tanaka et al. (2004), Liu et al. (2010) and Zheng et al. (2011) remain correct except that some species are facultatively anaerobic.

\section{Description of Catellibacterium nanjingense sp. nov.}

Catellibacterium nanjingense (nan.jing.en'se. N.L. neut. adj. nanjingense of or pertaining to Nanjing, Jiangsu Province, PR China, the geographical origin of the type strain).

Cells are Gram-stain-negative, catalase- and oxidase-positive, facultatively anaerobic, non-spore-forming, non-motile and short rods, $0.5-0.6 \mu \mathrm{m}$ in length and $1.0-1.2 \mu \mathrm{m}$ in diameter. After 3 days of incubation on 10-fold-diluted LB agar, colonies are $1.0-2.0 \mathrm{~mm}$ in diameter, white to beige, convex and circular with entire edges. Growth occurs in $0-4.5 \%(\mathrm{w} / \mathrm{v})$ $\mathrm{NaCl}$ (optimum $0.5 \%$ ), at $10-40{ }^{\circ} \mathrm{C}$ (optimum $28{ }^{\circ} \mathrm{C}$ ) and at pH 5.5-10.0 (optimum pH 7.0). Vesicular internal membrane structure was not detected and photoheterotrophic growth was not observed. Negative for hydrolysis of starch, Tween 20, Tween 80 and tyrosine. In the API 20NE test, positive for hydrolysis of aesculin, assimilation of D-glucose, D-mannose, maltose, mannitol, malate and $\mathrm{N}$-acetylglucosamine, and negative for urease, arginine dihydrolase, gelatinase, fermentation of glucose, nitrate reduction, indole production, and assimilation of arabinose, gluconate, caprate, adipic acid, citrate and phenylacetic acid. In the API ZYM test, positive for alkaline phosphatase, esterase C4, esterase lipase C8, lipase $\mathrm{C} 14$, leucine arylamidase, valine arylamidase, acid phosphatase, naphthol-AS-BI-phosphohydrolase, $\alpha$-glucosidase, $\beta$-glucosidase and $\beta$-galactosidase; negative for cystine arylamidase, trypsin, $\alpha$-chymotrypsin, $\alpha$-galactosidase, $N$ acetyl- $\beta$-glucosaminidase, $\alpha$-fucosidase, $\beta$-glucuronidase and $\alpha$-mannosidase. Major fatty acid is $\mathrm{C}_{18: 1} \omega 7 c / \mathrm{C}_{18: 1} \omega 6 c$. The major respiratory quinone is ubiquinone- 10 . The DNA G $+\mathrm{C}$ content is $63.7 \mathrm{~mol} \%$.

The type strain $\mathrm{Y} 12^{\mathrm{T}}$ (=CCTCC AB $2010218^{\mathrm{T}}=\mathrm{KCTC}$ $23298^{\mathrm{T}}$ ) was isolated from activated sludge in a wastewater bio-treatment facility in a pesticide manufacturing company in Nanjing city, Jiangsu province, PR China.

\section{Acknowledgements}

This work was supported by National Natural Science Foundation of China (30970099) and Transformation Fund for Agricultural Science and Technology Achievements (2009GB23600516).

\section{References}

Anil Kumar, P., Srinivas, T. N. R., Sasikala, Ch. \& Ramana, Ch. V. (2007). Rhodobacter changlensis sp. nov., a psychrotolerant, phototrophic alphaproteobacterium from the Himalayas of India. Int J Syst Evol Microbiol 57, 2568-2571.

Buck, J. D. (1982). Nonstaining (KOH) method for determination of gram reactions of marine bacteria. Appl Environ Microbiol 44, 992-993.

Chun, J., Lee, J.-H., Jung, Y., Kim, M., Kim, S., Kim, B. K. \& Lim, Y. W. (2007). EzTaxon: a web-based tool for the identification of prokaryotes based on 16S ribosomal RNA gene sequences. Int J Syst Evol Microbiol 57, 2259-2261.

Collins, M. D., Pirouz, T., Goodfellow, M. \& Minnikin, D. E. (1977). Distribution of menaquinones in actinomycetes and corynebacteria. J Gen Microbiol 100, 221-230. 
Cowan, S. T. \& Steel, K. J. (1965). Manual for the Identification of Medical Bacteria. London: Cambridge University Press.

Ezaki, T., Hashimoto, Y. \& Yabuuchi, E. (1989). Fluorometric deoxyribonucleic acid-deoxyribonucleic acid hybridization in microdilution wells as an alternative to membrane filter hybridization in which radioisotopes are used to determine genetic relatedness among bacterial strains. Int J Syst Bacteriol 39, 224-229.

Felsenstein, J. (1985). Confidence limits on phylogenies: an approach using the bootstrap. Evolution 39, 783-791.

Gregersen, T. (1978). Rapid method for distinction of Gram-negative from Gram-positive bacteria. Eur J Appl Microbiol Biotechnol 5, 123-127.

Guo, P., Wang, B. Z., Hang, B. J., Li, L., Ali, S. W., He, J. \& Li, S. (2009). Pyrethroid-degrading Sphingobium sp. JZ-2 and the purification and characterization of a novel pyrethroid hydrolase. Int Biodeterior Biodegradation 63, 1107-1112.

Hanada, S., Takaichi, S., Matsuura, K. \& Nakamura, K. (2002). Roseiflexus castenholzii gen. nov., sp. nov., a thermophilic, filamentous, photosynthetic bacterium that lacks chlorosomes. Int J Syst Evol Microbiol 52, 187-193.

Kämpfer, P. \& Kroppenstedt, R. M. (1996). Numerical analysis of fatty acid patterns of coryneform bacteria and related taxa. Can $J$ Microbiol 42, 989-1005.

Kimura, M. (1980). A simple method for estimating evolutionary rates of base substitutions through comparative studies of nucleotide sequences. J Mol Evol 16, 111-120.

Kroppenstedt, R. M. (1982). Separation of bacterial menaquinones by HPLC using reverse phase (RP-18) and a silver loaded ion exchanger. J Liq Chromatogr 5, 2359-2367.

Liu, Y., Xu, C.-J., Jiang, J.-T., Liu, Y.-H., Song, X.-F., Li, H. \& Liu, Z.-P. (2010). Catellibacterium aquatile sp. nov., isolated from fresh water, and emended description of the genus Catellibacterium Tanaka et al. 2004. Int J Syst Evol Microbiol 60, 2027-2031.

Mandel, M. \& Marmur, J. (1968). Use of ultraviolet absorbancetemperature profile for determining the guanine plus cytosine content of DNA. Methods Enzymol 12B, 195-206.

Ohta, H. \& Hattori, T. (1983). Agromonas oligotrophica gen. nov., sp. nov., a nitrogen-fixing oligotrophic bacterium. Antonie van Leeuwenhoek 49, 429-446.

Pfennig, N. \& Trüper, H. G. (1974). The phototrophic bacteria. In Bergey's Manual of Determinitive Bacteriology, 8th edn, pp. 24-75. Edited by R. E. Buchanan \& N. E. Gibbons. Baltimore, MD: Williams \& Wilkins.

Saitou, N. \& Nei, M. (1987). The neighbor-joining method: a new method for reconstructing phylogenetic trees. Mol Biol Evol 4, 406-425.
Sambrook, J. \& Russell, D. W. (2001). Molecular Cloning: a Laboratory Manual, 3rd edn. Cold Spring Harbor, NY: Cold Spring Harbor Laboratory.

Sasser, M. (1990). Identification of bacteria by gas chromatography of cellular fatty acids, MIDI Technical Note 101. Newark, DE: MIDI Inc.

Suzuki, M., Nakagawa, Y., Harayama, S. \& Yamamoto, S. (2001). Phylogenetic analysis and taxonomic study of marine Cytophaga-like bacteria: proposal for Tenacibaculum gen. nov. with Tenacibaculum maritimum comb. nov. and Tenacibaculum ovolyticum comb. nov., and description of Tenacibaculum mesophilum sp. nov. and Tenacibaculum amylolyticum sp. nov. Int J Syst Evol Microbiol 51, 16391652.

Tamura, K., Dudley, J., Nei, M. \& Kumar, S. (2007). MEGA4: molecular evolutionary genetic analysis (MEGA) software version 4.0. Mol Biol Evol 24, 1596-1599.

Tanaka, Y., Hanada, S., Manome, A., Tsuchida, T., Kurane, R., Nakamura, K. \& Kamagata, Y. (2004). Catellibacterium nectariphilum gen. nov., sp. nov., which requires a diffusible compound from a strain related to the genus Sphingomonas for vigorous growth. Int $J$ Syst Evol Microbiol 54, 955-959.

Tindall, B. J., Rosselló-Móra, R., Busse, H.-J., Ludwig, W. \& Kämpfer, P. (2010). Notes on the characterization of prokaryote strains for taxonomic purposes. Int J Syst Evol Microbiol 60, 249-266.

Wang, B. Z., Guo, P., Hang, B. J., Li, L., He, J. \& Li, S. P. (2009). Cloning of a novel pyrethroid-hydrolyzing carboxylesterase gene from Sphingobium sp. strain JZ-1 and characterization of the gene product. Appl Environ Microbiol 75, 5496-5500.

Wang, B.-Z., Guo, P., Zheng, J.-W., Hang, B.-J., Li, L., He, J. \& Li, S.-P. (2011). Sphingobium wenxiniae sp. nov., a synthetic pyrethroids (SP)-degrading bacterium isolated from activated sludge in a SPmanufacturing wastewater treatment facility. Int J Syst Evol Microbiol 61, 1776-1780.

Wayne, L. G., Brenner, D. J., Colwell, R. R., Grimont, P. A. D., Kandler, O., Krichevsky, M. I., Moore, L. H., Moore, W. E. C., Murray, R. G. E. \& other authors (1987). International Committee on Systematic Bacteriology. Report of the ad hoc committee on reconciliation of approaches to bacterial systematics. Int J Syst Bacteriol 37, 463-464.

Weed Science Society of America (1994). Herbicide Handbook, 7th edn, pp. 10-59. Champaign, IL: Weed Science Society of America.

Zheng, J.-W., Chen, Y.-G., Zhang, J., Ni, Y.-Y., Li, W.-J., He, J. \& Li, S.-P. (2011). Description of Catellibacterium caeni sp. nov., reclassification of Rhodobacter changlensis Anil Kumar et al. 2007 as Catellibacterium changlense comb. nov. and emended description of the genus Catellibacterium. Int J Syst Evol Microbiol 61, 1921-1926. 